\title{
Relative contribution of cysteine and methionine to glutathione content and thyroid hormone levels in the rat
}

\author{
By C. SUBERVILLE, P. HIGUERET, D. TARUOURA AND H. GARCIN \\ Laboratoire Physiologie de la Nutrition, Département Alimentation et Nutrition, \\ Université Bordeaux I, avenue des Facultés, 33405 Talence-Cédex, France
}

\author{
AND D. HIGUERET
}

Laboratoire Biochimie Médicale, Hôpital Pellegrin, Place Raba Léon, 33000 Bordeaux, France

(Received 29 July 1986 - Accepted 29 January 1987)

\begin{abstract}
1. For a period of $24 \mathrm{~d}$ rats were given diets containing either casein or pea (Pisum sativum) protein at two different concentrations $(180$ and $120 \mathrm{~g} / \mathrm{kg}$ ) without or with cysteine or cysteine + methionine supplementation.

2. The effects of these diets on levels of blood and liver reduced glutathione (GSH) and serum thyroid hormones were studied.

3. When compared with the $180 \mathrm{~g}$ casein $/ \mathrm{kg}$ diet, the $120 \mathrm{~g}$ casein $/ \mathrm{kg}$ diet decreased liver GSH and serum thyroid hormone concentrations. These changes were related to dietary cysteine supply since supplementation induced an increase in these variables.

4. When compared with $180 \mathrm{~g}$ pea protein $/ \mathrm{kg}$ diet, the $120 \mathrm{~g}$ pea protein $/ \mathrm{kg}$ diet decreased liver GSH and serum thyroid hormone concentrations. These changes could not be corrected by cysteine or cysteine + methionine supplementation.
\end{abstract}

Inadequate food intake produces various changes in hormonal status. For example it is known that vitamin A deficiency (Garcin \& Higueret, 1977; Morley et al. 1978; Higueret $\&$ Garcin, 1984a) or protein deficiency (see Brasel, 1980) induces changes in thyroid status. It is known also that reduced glutathione (GSH) plays several roles in thyroid hormone physiology, particularly in peripheral metabolism of thyroxine $\left(\mathrm{T}_{4}\right.$ ) (Balsam \& Ingbar, 1978; Chopra, 1978; Imai et al. 1980; Higueret \& Garcin, 1982) and in 3,5,3'-triiodothyronine $\left(\mathrm{T}_{3}\right)$ cellular uptake (Higueret \& Garcin, 1984b). It is thus of interest to study the effects of sulphur-amino acid-deficient diets on tissue GSH contents and, also, on thyroid hormone changes.

According to Sowers et al. (1972) and Stockland et al. (1973), cysteine (Cys) and methionine (Met) deficiencies appear in the rat when the dietary supply of Cys and Met are lower than 2.8 and $1.7 \mathrm{~g} / \mathrm{kg}$ respectively. In the present study, deficiencies were produced by using either casein or a pea (Pisum sativum) isolate as the protein source at 120 or $180 \mathrm{~g} / \mathrm{kg}$ diet. Cys or Cys + Met supplementation was used to correct deficiencies in protein intake.

\section{METHODS \\ Animals and experimental procedure}

Male Wistar rats were obtained from IFFA Credo (l'Arbresle, France). They were housed in an air-conditioned room with a mean temperature of $21 \pm 1^{\circ}$, were weighed daily and the food intake calculated. Water and diets were offered ad lib.

Expt 1. Twenty-eight rats with an initial weight of 130-140 g, were randomized into three groups: one group of eight rats and two groups of ten rats each. They were fed for $28 \mathrm{~d}$ on one of the following three semi-purified diets $(\mathrm{g} / \mathrm{kg})$ : casein 180 , casein 120 , casein $120+1.93$ L-Cys (Table 1). 
Table 1. Composition of the diets $(\mathrm{g} / \mathrm{kg})$

\begin{tabular}{|c|c|c|c|c|c|c|}
\hline \multirow[b]{2}{*}{ Ingredients } & \multicolumn{6}{|c|}{ Diet } \\
\hline & $\begin{array}{c}\text { Casein } \\
180\end{array}$ & $\begin{array}{c}\text { Casein } \\
120\end{array}$ & $\begin{array}{c}\text { Casein } \\
120+\text { Cys }\end{array}$ & $\begin{array}{c}\text { Pea }^{*} \text { protein } \\
180\end{array}$ & $\begin{array}{l}\text { Pea protein } \\
120+\text { Cys }\end{array}$ & $\begin{array}{c}\text { Pea protein } \\
120+\text { Cys }+ \text { Met }\end{array}$ \\
\hline Casein (vitamin-free) $\dagger$ & 180 & 120 & 120 & - & - & - \\
\hline Pea $(800$ g protein $/ \mathrm{kg}) \ddagger$ & 0 & - & - & 219 & 157 & 157 \\
\hline Potato starch & 400 & 436 & 434 & 381 & 428 & 428 \\
\hline Sucrose & 315 & 339 & 339 & 308 & 329 & 329 \\
\hline Salt mixture§ & 40 & 40 & 40 & 40 & 40 & 40 \\
\hline Vitamin mixture" & 10 & 10 & 10 & 10 & 10 & 10 \\
\hline Agar agar & 5 & 5 & 5 & 6 & 6 & 6 \\
\hline Peanut oil & 50 & 50 & 50 & $30^{\circ}$ & 369 & $36 \pi$ \\
\hline L-Cysteine (Cys) & - & - & 1.93 & - & 0.8 & 0.8 \\
\hline L-Methionine (Met) & - & - & - & - & - & 0.6 \\
\hline
\end{tabular}

* Pisum sativum

† USB - 12866; United States Biochemical Corporation, Ohio.

¥ Institut National de la Recherche Agronomique, Nantes.

$\S$ USB - 21420; United States Biochemical Corporation. Contained $(\mathrm{g} / \mathrm{kg}): \mathrm{CaCO}_{3} 210, \mathrm{CuSO}_{4} .5 \mathrm{H}_{2} \mathrm{O} 0.39$, $\mathrm{Fe}_{2}\left(\mathrm{PO}_{4}\right)_{3} 14.70, \mathrm{MnSO}_{4}$ anhydrous $0.20, \mathrm{MgSO}_{4}$ anhydrous $90, \mathrm{KAl}\left(\mathrm{SO}_{4}\right)_{2} 0.09, \mathrm{KCl} 120, \mathrm{KH}_{2} \mathrm{PO}_{4} 310, \mathrm{KI} 0.05$, $\mathrm{NaCl} 105, \mathrm{NaF} 0.57, \mathrm{Ca}_{3}\left(\mathrm{PO}_{4}\right)_{2} 149$.

II USB - 23431; United States Biochemical Corporation. Contained $(\mathrm{g} / \mathrm{kg})$ : ascorbic acid 45.00 , thiamin 1.00 , riboflavin 1.00 , pyridoxin 1.00 , niacin 4.50 , D-calcium pantothenate 3.00 , inositol 5.00 , choline 75.00 , biotin 0.02 , folic acid 0.09, vitamin $\mathbf{B}_{12} 0.00135$, menadione $2.25, \alpha$-tocopherol 5.00, calciferol $\left(\mathrm{D}_{2}\right) 0.0025$, vitamin $A$ acetate 0.31 .

If Equivalent to $50 \mathrm{~g}$ total lipid $/ \mathrm{kg}$ as the pea isolate contained $90 \mathrm{~g} \mathrm{lipid} / \mathrm{kg}$.

Expt 2. Twenty-four rats with an initial weight of 110-120 g, were randomized into three groups of eight rats each. They were fed for $24 \mathrm{~d}$ on one of the following three semi-purified diets $(\mathrm{g} / \mathrm{kg})$ : pea protein 180 ; pea protein $120+0.8 \mathrm{~L}-\mathrm{Cys}$; pea protein $120+0.8$ L-Cys + 0.6 L-Met (Table 1).

At the end of the experimental period (Expts 1 and 2) the animals were killed by decapitation at 09.00 hours and blood and liver were very rapidly collected. The time between animal removal from the cages and blood collection was less than $30 \mathrm{~s}$; an additional $30 \mathrm{~s}$ elapsed before washing excised liver in ice-cold buffer. A portion of blood was immediately used for glutathione analysis, the remainder was allowed to clot and the serum was stored at $-23^{\circ}$. The liver was weighed and a portion used immediately for glutathione and protein analyses, the remainder was frozen in liquid nitrogen and stored at $-80^{\circ}$ for subsequent analysis. This method of killing and sampling minimized possible effects on the measured indices. GSH content, which is probably the most labile compound studied, was apparently not affected since the reduced form represented more than $97 \%$ of total glutathione.

\section{Analytical procedure}

Hormone assays. Serum $\mathrm{T}_{4}$ was determined by the competitive-binding assay of Murphy \& Jachan (1965) adapted by Vigouroux (1972); serum $T_{3}$ was determined by the specific double-antibody radioimmunoassay of Chopra et al. (1972) adapted by Jordan et al. (1980).

Liver enzyme activities. Glucose-6-phosphate dehydrogenase (EC 1.1.1.49;G6P-DH) and phosphogluconate dehydrogenase (decarboxylating) (EC 1.1.1.44; PG-DH) were assayed according to Löhr \& Waller (1965) and King (1965). 


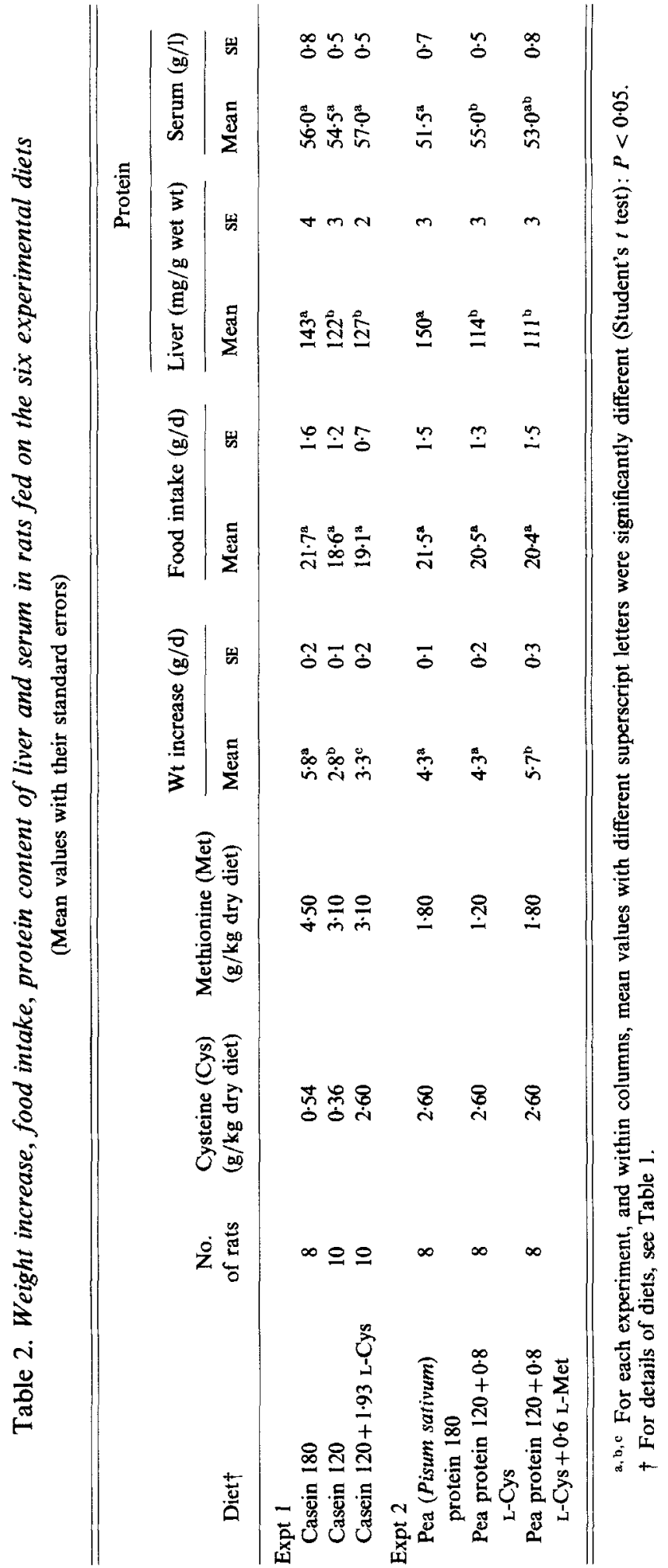




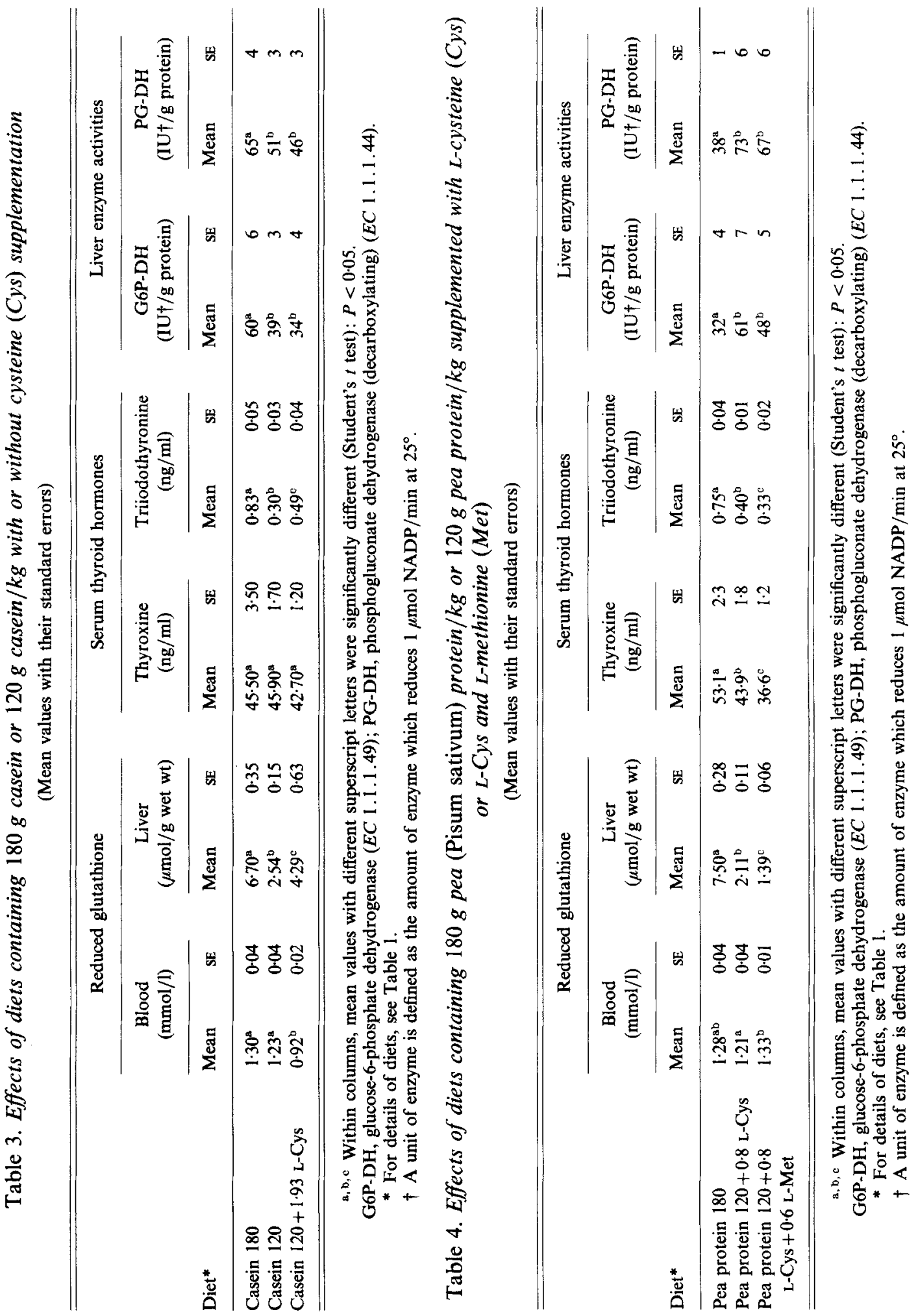


Protein assays. Serum and liver proteins were measured according to Bradford (1976) using the Bio-Rad protein assay (Bio-Rad laboratories, Munich, West Germany).

GSH assay. Enzymic analysis was performed according to Akerboom \& Sies (1981).

\section{Statistical analysis}

Results were compared using Student's $t$ test. Differences in mean values were considered significant at $P<0.05$.

\section{RESULTS \\ Expt 1}

Effects of the diet containing $120 \mathrm{~g}$ casein $/ \mathrm{kg}$. As can be seen from Tables 2 and 3, reducing protein intake from 180 to 120 decreased body-weight gain and changed some liver and blood chemical indices. There were decreases in liver proteins, in liver enzyme activities of the pentose phosphate cycle, and in liver GSH content (whereas blood GSH was not affected). The serum level of $T_{4}$ was unchanged whereas that of $T_{3}$ was strongly decreased.

Effects of a diet containing $120 \mathrm{~g}$ casein $/ \mathrm{kg}$ supplemented with $1.93 \mathrm{~g} \mathrm{~L}-\mathrm{Cys} / \mathrm{kg}$. Compared with animals fed on the unsupplemented $120 \mathrm{~g}$ casein $/ \mathrm{kg}$ diet, there was a higher bodyweight gain, increased liver GSH content and serum level of $T_{3}$. However none of these variables reached the values measured in rats fed on a $180 \mathrm{~g}$ casein $/ \mathrm{kg}$ diet. The liver proteins and the liver enzyme activities of the pentose phosphate cycle remained at a low level.

\section{Expt 2}

Effects of a diet containing $120 \mathrm{~g}$ pea protein $/ \mathrm{kg}$ supplemented with $0.8 \mathrm{~g} \mathrm{~L}$-Cys. Tables 2 and 4 show that, when compared with $180 \mathrm{~g}$ pea protein $/ \mathrm{kg}$, this diet did not induce a change in body-weight gain but produced a decrease in liver GSH content (blood GSH was not affected) and in serum levels of $T_{4}$ and $T_{3}$. There was a marked decrease in liver proteins and an unexpected increase in the activities of the pentose phosphate cycle liver enzymes.

Effects of a diet containing $120 \mathrm{~g}$ pea protein $/ \mathrm{kg}$ supplemented with $0.8 \mathrm{~g} \mathrm{~L}$-Cys and 0.6 g L-Met. With supplementation there was a higher decrease in the liver GSH content and the serum levels of both $T_{4}$ and $T_{3}$. The activities of the pentose phosphate cycle liver enzymes remained at a high level. The body-weight gain was increased compared with that of rats fed on either a $180 \mathrm{~g}$ pea protein $/ \mathrm{kg}$ diet or a $120 \mathrm{~g}$ pea protein $/ \mathrm{kg}$ diet supplemented with $0.8 \mathrm{~g} \mathrm{~L}-\mathrm{Cys} / \mathrm{kg}$ only.

\section{DISCUSSION}

In the present study liver proteins were a better index of nutritional status than serum proteins which remained unchanged following reduction in dietary casein. It was also observed that when the liver protein concentration decreased, liver GSH content decreased, but it is not known if these changes were causally related. The $120 \mathrm{~g}$ casein $/ \mathrm{kg}$ diet induced low levels of liver GSH because of Cys deficiency. This defect can be corrected either by Cys supplementation $(120 \mathrm{~g}$ casein $+1.9 \mathrm{~g} \mathrm{~L}-\mathrm{Cys} / \mathrm{kg}$ ) or by Cys resulting from the metabolization of part of the large amount of Met contained in the $180 \mathrm{~g}$ casein $/ \mathrm{kg}$ diet. It is known that when L-Met increases in the diet, the amount of L-Cys produced from L-Met inevitably increases (Tateishi et al. 1981). Cho et al. (1984), using amino acid mixtures with levels of Cys and Met similar to those supplied in the diets used in the present experiments, observed similar changes in the liver GSH content. Normal levels of liver GSH were observed with the $180 \mathrm{~g}$ pea protein $/ \mathrm{kg}$ diet. Reduction of the pea protein from 180 to $120 \mathrm{~g} / \mathrm{kg}$ reduced 
the level of liver GSH even with Cys or with Cys + Met supplementation. Thus other factors are probably implicated in the determination of the GSH levels. These factors may be related to the specific amino acid content of untreated pea protein, or the drastic technology applied in the preparation of the protein which could have reduced the availability of some amino acids, or both. These factors might interfere with Cys and Met levels and thus GSH metabolism.

The GSH level of blood, which essentially reflects the GSH level in erythrocytes (Akerboom \& Sies, 1981), was not affected by the different diets used. This finding is in agreement with that of Cho et al. (1984).

The effects of a reduced protein intake on serum thyroid hormone levels were not clear (Brasel, 1980). Studies on rats fed on a low-protein diet have shown either an increase (Ingbar \& Galton, 1975; Okamura et al. 1981) or a decrease (Yousef \& Johnson 1968; Schussler \& Orlando, 1978; Hasting \& Zeman, 1979) in these levels.

The present results show that when the protein contained a satisfactory amino acid balance (i.e. casein), the reduction of protein intake $(120 \mathrm{~g} / \mathrm{kg}$ diet $)$ did not affect the serum $\mathrm{T}_{4}$ level. On the contrary, when the protein supplied was the pea protein the reduction in intake produced a decrease in $\mathrm{T}_{4}$ even with $\mathrm{L}$-Cys or L-Cys $+\mathrm{L}-\mathrm{Met}$ supplementation. This decrease cannot be attributed to an increased metabolization of $T_{4}$ since the main metabolic pathway is a 5 -monodeiodination (Oppenheimer et al. 1970) using a monodeiodinase for which GSH is a cofactor (Visser et al. 1976; Chopra, 1978; Imai et al. 1980). However, it may be attributed to a decreased $\mathrm{T}_{4}$ production resulting from a decreased hormonal synthesis by the gland and not from an inadequate supply of specific amino acids since the levels of phenylalanine (Phe) and tyrosine (Tyr) are similar in casein and in pea protein ( $44 \mathrm{~g}$ Phe and $56 \mathrm{~g} \mathrm{Tyr} / \mathrm{kg}$ casein; $51 \mathrm{~g}$ Phe and $35 \mathrm{~g}$ Tyr $/ \mathrm{kg}$ pea protein).

In the rat the majority of $T_{3}$ results from the peripheral deiodination of $T_{4}$ (Abrams $\&$ Larsen, 1973). The present results show that when diets which affect liver GSH content are used there is a corresponding decrease in $\mathrm{T}_{3}$ serum levels. Therefore the level of liver GSH could be implicated in the decrease in serum $\mathrm{T}_{3}$ level reported in human protein -energy malnutrition and attributed, at least in part, to a decreased deiodination (Ingenbleek \& Beckers, 1975). $T_{3}$ is known to be one of the factors which regulate the activities of the pentose phosphate cycle enzymes (Mariash et al. 1980). The results obtained in the present study show that the effect of $T_{3}$ on these enzymes is modulated by the quantity and quality of the dietary protein. In Expt 1 the reduction from $180 \mathrm{~g}$ to $120 \mathrm{~g}$ casein $/ \mathrm{kg}$ diet induced a decreased $T_{3}$ serum level and decreased enzyme activities. When the $120 \mathrm{~g}$ casein $/ \mathrm{kg}$ diet was supplemented with Cys there was a small but significant increase in serum $T_{3}$ but no change in enzyme activities. The results obtained in Expt 2 using pea protein are more complex and less easy to explain. The enzyme activities measured in rats receiving the $180 \mathrm{~g}$ pea protein $/ \mathrm{kg}$ diet were reduced when compared with that of rats receiving the $180 \mathrm{~g}$ casein $/ \mathrm{kg}$ diet. This could be due to an amino acid imbalance in the pea-protein preparation. The reason for the increased enzyme activities observed when $120 \mathrm{~g}$ pea protein $/ \mathrm{kg}$ diet was supplemented with either Cys or Cys + Met, however, is not obvious.

\section{REFERENCES}

Abrams, G. M. \& Larsen, P. R. (1973). Journal of Clinical Investigation 52, 2522-2531.

Akerboom, T. P. M. \& Sies, H. (1981). Methods of Enzymology 77, 372-373.

Balsam, A. \& Ingbar, S. H. (1978). Clinical Research 26, 489A.

Bradford, M. M. (1976). Analytical Biochemistry 72, 248-254.

Brasel, J. A. (1980). Pediatric Research 14, 1299-1303.

Cho, E. S., Johnson, N. \& Snider, B. C. F. (1984). Journal of Nutrition 114, 1853-1862.

Chopra, I. J. (1978). Science 199, 904-906.

Chopra, I. J., Ho, R. S. \& Lan, R. (1972). Journal of Laboratory and Clinical Medicine 80, 729-739. 
Garcin, H. \& Higueret, P. (1977). Comptes Rendus Hebdomadaires des Séances de l'Académie des Sciences, Paris $285,531-533$.

Hasting, M. M. \& Zeman, F. J. (1979). Journal of Nutrition 109, 1925-1933.

Higueret, P. \& Garcin, H. (1982). Annals of Nutrition and Metabolism 26, 191-200.

Higueret, P. \& Garcin, H. (1984a). Journal de Physiologie, Paris 79, 373-377.

Higueret, P. \& Garcin, H. (1984b). Annales d'Endocrinologie 45, 149-150.

Imai, Y., Kataoka, N. \& Nishikimi, M. (1980). Endocrinologia Japonica 27, 201-207.

Ingbar, S. H. \& Galton, V. A. (1975). Endocrinology 96, 1525-1532.

Ingenbleek, Y. \& Beckers, C. (1975). Lancet i, 845-852.

Jordan, D., Rousset, B., Perrin, F., Fournier, M. \& Orgiazzi, J. (1980). Endocrinology 107, 1245-1248.

King, J. (1965). In Methods in Enzymatic Analysis, pp. 632 635 [H. Bergmayer, editor]. New York: Academic Press.

Löhr, G. W. \& Waller, H. D. (1965). In Methods in Enzymatic Analysis, pp. 636-643 [H. Bergmayer, editor]. New York: Academic Press.

Mariash, C. N., Kaiser, F. E. \& Oppenheimer, J. H. (1980). Endocrinology 106, $22-27$.

Morley, J. E., Melmed, S., Redo, A., Kasson, B. G., Levin, S. R., Pekary, A. E. \& Hershman, J. M. (1978). American Journal of Physiology 238, E174-E179.

Murphy, B. P. \& Jachan, C. (1965). Journal of Laboratory and Clinical Medicine 66, 161-167.

Okamura, K., Taurog, A. \& Krulich, L. (1981). Endocrinology 108, 1247-1256.

Oppenheimer, J. H., Schwartz, H. L., Shapiro, H. C., Bernstein, G. \& Surks, M. (1970). Journal of Clinical Investigation 49, 1016-1024.

Schussler, G. C. \& Orlando, J. (1978). Science 199, 686-687.

Sowers, J. E., Stokland, W. L. \& Meade, R. (1972). Journal of Animal Science 35, 782-788.

Stockland, W. L., Meade, R. J., Wass, D. J. \& Sowers, J. E. (1973). Journal of Animal Science 36, 526-530.

Tateishi, N., Higashi, T., Naruse, A., Hikita, K. \& Sakamoto, Y. (1981). Journal of Biochemistry 90, 1603 1610.

Vigouroux, E. (1972). Comptes Rendus Hebdomadaires des Séances de l'Académie des Sciences, Paris 275, 579582.

Visser, T. J., Van Der Does-Tobe, T., Docter, R. \& Henneman, G. (1976). Biochemical Journal 157, 479-482.

Yousef, M. K. \& Johnson, H. D. (1968). Endocrinology 82, 353-358. 